\title{
Discomfort in Ethnography. Methodological Questions, Choices and Tools in Sensitive Contexts
}

\section{Abstract}

This article discusses ethnographic research conditions in "sensitive" or "dangerous" field sites especially in areas of conflict and violence, drawing on recent short fieldworks in Western Sahara. The reflection considers the different situations that cause discomfort for the researcher in these field sites, as well as the heuristic opportunities that this discomfort generates for the ethnographer, obliging him to renew his approaches, to reconsider his objects, and rethink his relationship with the field and his interlocutors.

Keywords: ethnography, discomfort, methodology, conflict, Western Sahara.

Over the last two decades, anthropologists' fieldwork conditions have notably changed, giving rise to new methodological problems and leading ethnographers to study new objects with innovative approaches. This essay will question ethnographic study conditions in "sensitive" or "dangerous" grounds: if each field of investigation has its own specificities, some appear more "mined" than others. This is especially true in areas of conflict and violence, such as Western Sahara where I have been conducting short fieldwork (trips) since 2011 and from which I will sustain the following reflections.

Since the premature departure of the Spanish colonial forces in 1976, the Western Sahara territory over which the Sahrawi population claims sovereignty is occupied in its western two-thirds by the Moroccan State and controlled in its eastern third by the Polisario Front and the Sahrawi Arab Democratic Republic. ${ }^{1}$

\footnotetext{
${ }^{1}$ For more ethnographic works on the SADR, see for instance: Caratini 2003 and Wilson 2016.
} 
The SADR was founded in February 1976 in exile in the refugee camps of Tindouf (Algeria) where today most of the population whom SADR governs lives. Since the 1991 ceasefire between the two opposing parties and the endless expectation of the United Nations referendum on self-determination, the conflict drags on (see Zunes \& Mundy 2010) and is clearly shifting to the economic (exploitation of natural resources), legal (European Court of Justice in Brussels, Human Rights Committee in Geneva, $4^{\text {th }}$ UN Commission in New York) and media (social networks, satellite TV channels) spheres.

The present article $^{2}$ will examine the difficulties of setting up social science tools and methodologies in this type of context, focusing on different issues including the impacts of the researcher's presence on his relationships with people and local authorities (trust and suspicion issues, power relationships...), the emotional and moral experiences of the researcher and their effects on the fieldwork conduct, and the epistemic issue of creating distance from the Other in sensitive or even tragic circumstances. All these aspects of the ethnographic study comprise what Sophie Caratini (2012) called the "unspoken of anthropology", although they are essential to the validation of ethnographic data.

Among the many conditions that can give the fieldwork a particularly sensitive and even dangerous dimension (the high degree of vulnerability of a population, dictatorial political context, research on a very taboo subject, situation of strong social discrimination, a painful postcolonial relationship, etc.), I will limit myself here to the contexts of armed political conflict between two opposed parties claiming sovereignty over the same territory.

Drawing on recent ethnographic experiences in Western Sahara, I will start with some general reflections on the sensitive nature of the ethnographic "terrain", then I will discuss the researcher's position in this type of situation and highlight the opportunities that this type of "terrain" seems to offer us to renew our objects and our approaches, and I will conclude with some ethical questions that need to be addressed in these specific ethnographic situations.

2 The reflections presented in this text were developed in the doctoral seminar "Enqueter en terrain sensible" co-animated with Pénélope Larzillière (IRD) within the Doctoral School (ED 180) of the Faculty of Human and Social Sciences of the Sorbonne (Paris Descartes University) on January $19^{\text {th }}$ and $26^{\text {th }}, 2017$, and during an ERASMUS stay at the Institute of Ethnology of the Jagiellonian University in Cracow, from April $10^{\text {th }}$ to $15^{\text {th }}, 2017$. I address my warmest thanks to colleagues and students, French and Polish, who attended these seminars, for their stimulating inputs. I also wish to kindly thank Alice Wilson for her very careful reading of the final draft of the paper. 


\section{General reflections on the sensitive nature of fieldwork in ethnography}

Before assessing what makes a fieldwork "sensitive" for anthropologists and ethnographers, in the wake of three (relatively) recent publications in France (Albera 2001; Bouillon, Fresia \& Tallio 2006; Ayimpam 2015; Bouju 2015), it can be useful to first discuss the meaning of "fieldwork" for anthropologists.

This term refers to the classical methods in ethnology and anthropology. In French, the word "terrain" would be literally the equivalent of "field site" in English, implying at the same time the place and the population of inquiry. It refers to Malinowski's (1985; 1989 [1922]) principles of ethnographic studies, an approach which is at the same time inductive, emic and holistic (Ayimpam 2015; Bouju 2015): an individual experience in immersion in a society and its culture and language, which combines familiarization and distancing from the Other; a long fieldtrip ( 1 or 2 years) and language learning, in order to cut all ties with one's society; a global approach interested in all aspects of everyday life; a diary recording all aspects of the fieldwork experience; the cornerstone principle of "participating observation" consisting of taking part in social life, rituals, technical operations, etc. while simultaneously observing as an outsider. The general objective is to understand a society from inside, its way of thinking, its symbolic system, its categories of thought, etc.

The anthropologist's fieldwork has been constructed as the exclusive mode of ethnographic data production in anthropology, as Hagberg and Körling point out (2015: 148), and this is what I am still generally teaching to my students! But, what happens when fieldwork is not really or no longer possible in the "Maliowskian conditions"? Another question is the idea of control over one's "terrain". To keep control over the research and to make the right choices in the right times is usually what we teach to students, but isn't there a kind of illusion in this idea? As many authors like Schinz (2002) discuss, the "Other" constructs and impacts our fieldwork more than the ethnographer does. So isn't it necessary to assume a certain kind of "flottement"/"laisser-faire" as proposed by Pétonnet (1982), which means to let things come to us (instead of trying at any cost to make all the decisions) and to be attentive to what "Others" do to/with our research and fieldwork. ${ }^{3}$ Moreover, Clifford (2003) has shown how, since the 1950s, the monologic authority of the ethnographer, based solely on his fieldwork experience, has entered a crisis and dispersed into other forms authority (interpretative, dialogic, polyphonic).

In fact, isn't any terrain "sensitive" when we always have to negotiate the perilous compromise between empathy with and distance from Others, between

${ }^{3}$ Among an important literature on this topic, see for instance: Marcus 1995; Rabinow, Marcus, Faubion \& Rees 2003. 
the "identities" that we have to endorse according to our "personal equation", between engagement and neutrality, between assumed subjectivity and illusory objectivation of the "realities"? For an Africanist like Jean-Pierre Dozon, in fact, "ethnological grounds have always been sensitive"5 (2006: 7).

Nevertheless, some fieldwork seems more comfortable than others as anthropologists realize during their career and especially when they change their research subjects and/or their region of investigation. Personally, I realize today that my fieldwork experience have become more and more sensitive during these last twenty years. Also because my personal situation has changed, I have become more attentive to political problems than I was twenty years ago, etc. Firstly, my 18 month doctoral fieldwork studying livelihood changes of pastoralists in Mauritania (1999-2000) was conducted in very spartan conditions (and then considered "dangerous" by my relatives) and did not appear to me "sensitive" at that time - nor today with hindsight. This makes us realize the eminently relative and subjective character of the sensitivity of fieldwork: for the ethnographer, his family circle, his colleagues, his employer, etc. Secondly, my investigations on the birth of a touristic economy in Northern Mauritania (2005-2006) and its social impacts became more sensitive, because of conflict situations between Mauritanian actors in the tourism industry and strong economic competition. Thirdly, during my research on social changes amongst Imraguen fishermen of the Banc d'Arguin National Park on the Mauritanian littoral (2006-2009), ethnographic studies were particularly difficult to conduct because of rising tensions between the National Park administration, Nature Conservation NGOs and local Imraguen communities around issues of access to natural resources. But there is no comparison with my most recent fieldwork in Western Sahara (2011 to present), where I was under targeted political control, especially in the part occupied by Moroccan forces. The ethnographer's feeling not only depends on her/his age, experience and life-stage, but also on the time spent doing fieldwork.

As Albera noticed (2001), this issue of comfort/discomfort in conducting field research is often discussed in the literature in terms of efficiency and even "profitability" in ethnographic data production. Fieldwork discomfort can happen in different situations, and can include dislike (van Wyk 2013), fear and reprisals on the researcher, especially in contexts of conflict, as described by Moussaoui (2001) for instance in the "Black decade" in Algeria 1990s. More generally, authors agree on the fact that, since 30 years, with globalization, and especially since the advent of the Internet in the past 20 years, Otherness and exotism (Bensa 2006) are no longer the exclusive topoi of anthropologists.

As a matter of fact, anthropologists have had to rethink their "Ailleurs" (elsewhere) and they have now to share "exotic" grounds with other actors: NGO employees, militaries, journalists, Human Rights Observers, etc. Moreover, anthro-

${ }^{4}$ For a discussion on anthropology "at home", see for instance: Ouattara 2004.

${ }^{5}$ All extracts of texts published in French have been translated into English by us. 
pology remains (unfortunately) largely a science of Westerners or a Eurocentric science, which gives more rise to suspicion and rejection from populations that we appraise. A strong asymmetry always remains between the ethnographer's position and the groups he is interested in (Albera 2001).

\section{The ethnographer's position: from observer to actor}

So how to place oneself in these specific ethnographic relationships? Of course, the question is not new! Remember some of our forbearers at the end of the colonial period (Leiris 1950; Balandier 2001) or in the context of resistance in France during the $2^{\text {nd }}$ World War or the "Guerre d'Algérie" and for instance Germaine Tillion. ${ }^{6}$ For many authors that we consulted, it is the fieldwork relationship that is problematic and of course the perception by the population appraised of the ethnographer's position. We must always gain and regain the population's confidence in what we do, explain our role and objectives and sometimes we leave our researcher role to endorse other activities and engagements. We are pushed to play our role of anthropologist, and even to over-play it in order to be accepted as a researcher which can also affect the research process and our autonomy (Ayimpam 2015; Bouju 2015). In a conflict context, the ethnographer becomes not only an observer, but also an actor of the political and media scene (Prud'homme 2015). More than ever and more than anywhere else, the ethnographic relationship in sensitive context is often presented by scholars as a relationship of gift and counter-gift.

For my first research trip to Western Sahara in July 2011, my objective was to find a Sahrawi friend met in Barcelona a year before, and analyze a poem he had introduced me to. Because my friend was living in what the Sahrawi call "the occupied territories" of Western Sahara, which are under the control of Moroccan forces, I first thought that I had to obtain Moroccan research permits, which I did not obtain. However, Western Sahara is not recognized by international law as a Moroccan territory but as a non-governed territory waiting for a referendum of self-determination. In this type of situation, the political power, in return for its "green light", obliges us to take sides and to regularly give signs of collaboration. Doing fieldwork under tight political control also obliges one to carefully employ the "right" vocabulary, especially with authorities. For instance, with Moroccan authorities "Moroccan Sahara" and "southern regions" are used instead of Western Sahara, Hassani ${ }^{7}$ culture instead of Sahrawi culture, etc. In the refugee camps:

${ }^{6}$ On Germaine Tillion's engagements, see: Todorov 2007.

7 This term, which refers to the Hassaniyya language and its speakers, allows the Moroccan authorities to avoid using the ethnonym "Sahrawi", which refers directly to the population from Western Sahara waiting for the application of its right to self-determination. 
"occupied territories" and "liberated territories", "the Black March" instead of the "Green march", etc.

Thinking that an official authorization was essential for me to go as a researcher and for the first timein the area of Western Sahara under Moroccan occupation, I was put in contact with the "Agence du Sud", which is the development arm of the Moroccan administration in Western Sahara and which also espouses a mission of promotion of the local cultural heritage. This agency had asked me to come and present myself at its headquarters in Rabat but had refrained from granting me a written authorization, asking me "only" to make visits to its branches in the various localities of the "South of the kingdom" and to be reachable by mobile phone during my one month stay.

I had deliberately presented a very broad and "neutral" anthropological research project focused on the pastoral economy, allowing me to disguise my real intentions (the translation and contextualization of a long panegyric performed by a poet from the Tindouf refugee camps ${ }^{8}$ ) and to grant me some freedom of movement on the ground. Of course, I voluntarily omitted to acquire a Moroccan cell phone number and made my phone calls to the "Agence du Sud" from public booths. In retrospect, I believe that this first field mission, during which I kept my distance from the Moroccan administration and refused any material support, enabled me to discover concretely the situation on the ground firsthand and the complicated conditions for deeper ethnographic research. Three years later, during a second fieldtrip in July 2014, I was very quickly and routinely shadowed by Moroccan policemen and/or militiamen in civilian clothes. Today, I would be immediately expelled at my arrival at the airport as are most Western journalists and human rights defenders.

In this type of fieldwork conditions, when we meet our interviewees, we always have to clarify our "position" and to say who sends us and who protects us in order to gain their confidence. Field access becomes very complex when we try to get off the path on which we were supposed to stay, for example to meet human rights activists in the territories occupied by Morocco or political dissidents in the refugee camps under the administration of the Polisario Front. And of course the relatively short time of this kind of fieldtrip (from two weeks to one month) doesn't help in setting up confident relationships. Very often, the communication conditions change in the course of the interview as I experienced in Dakhla in July 2011. Through a Sahrawi correspondent of the Agence du Sud in this city under Moroccan occupation, I got an interview with a man who started to give me a very official speech on the history of the fishing families of this locality and on the benefits of the Moroccan presence. Over the course of the interview, his son (about 25 years old) and his wife invited themselves into the conversation and started to criticize the policy of overexploitation of the seabed by Moroccan boats to the

\footnotetext{
${ }^{8}$ For an account of this ethnographic enterprise, see: Boulay 2015.
} 
detriment of young local fishermen. This intervention revealed discord between the person I was supposed to interview and his relatives, who saw in the interview an opportunity to discuss some important political issues related to the situation of occupation and the impoverishment of young Sahrawis.

Furthermore, we have to wonder for whom the fieldwork is dangerous. We always talk about the anthropologist coming from abroad and risking her/his life. During my last fieldtrip in Laayoune (capital of the "occupied part") in July 2014, I had to endure shadowing and intimidation in the reception hall of my hotel and in the streets. But what about the persons surveyed who welcome the researcher at home, taking risks for themselves and their family? The fear of putting their lives in danger often leads us to postpone an interview or to take extreme precautions to meet as discreetly as possible a person who seems indispensable to the advancement of our research as discreetly as possible. The risks are even greater for the "informants" who work permanently with us in the field and who will have to face the reprisals of the authorities for their collaboration, but whose role in the research will usually stop at the end of the anthropologist's mission on the ground. More complex is the situation of the "autochthonous" anthropologist whose research and publications can destroy a career or even endanger her/his life and that of her/his family (Moussaoui 2001).

\section{Ethnographic renewal in sensitive grounds?}

Authors agree on the capacity of these experiences to encourage us to question, more than elsewhere, our ethnographic practices and methodologies. Indeed, these "sensitive" field conditions impact the way we implement our research projects. Of course, the ethnographic study temporalities in urgent and rapidly changing social situations directly influence our posture and identity for Others on the ground. Confident relationships are hard to set up and increase our dilemmas in the choice of our interlocutors: who am I supposed to see or avoid? What freedom do I have to meet this or that person?

These conditions generally push us to methodological innovations: short fieldtrips and the lack of immersion lead to more journalistic approaches with more interviews and less observation and description. They also encourage us to renew our objects of investigation, with new questions for example around the Web and the circulation of digital productions (which can be easier to access without field immersion).

But how can we expand anthropological knowledge on a conflict when field access is so restricted and fieldtrips so short? How can we avoid politically correct or overused key informants who are profiled in the work of other researchers, media sources, and amongst political actors of the conflict? The temptation is often to choose taboo subjects (betrayal, religious radicalism, prostitution, drugs, 
repression, etc.). For example, during my first fieldtrip in the "occupied territories", I heard about the question of Sahrawi returnees ('ầidîn) to the Moroccan side. Then I started collecting satirical poetry on these figures, poetry that was stressing a very important demographic issue about the populations' movements between the refugee camps and the so-called "occupied territories" (Boulay 2016). From that subject, I started inquiring about the use of humor, mockery and derision in the Sahrawi poetry, which are different channels to express political critics (Boulay 2017). Some important works had already appeared on the nationalist Sahrawi poetry by a few researchers (for instance Deubel 2012, 2017; Robles Picón et al. 2015) but none on these specific types of poetry and songs. This new topic sheds light on the political tensions and dissent within the Sahrawi population, using humor and mockery to denounce one's bad choice or behavior, or to criticize politicians and power. Our approach was similar with the Web: the idea was not to watch all the Sahrawi web production but to focus on (1) the successful poetic and musical productions, (2) their reception in Sahrawi audiences, and (3) their impacts on political positions and choices.

Discomfort and short fieldtrips under surveillance are often presented by scholars like Fassin (2006) as stimulating situations, pushing ethnographers to invent original and creative modes of investigations. In Western Sahara, I made three main choices of investigation. First, I tried to privilege multi-sited and multi-scalar fieldwork, between Mauritania, the "occupied territories" of Western Sahara, Southern Morocco and the Tindouf refugee camps and the SADR: my idea was to circulate between these spaces taking recordings of poems along with me, following poets and poems' trajectories between places, and gathering audiences' comments on these poems, beyond national frontiers and beyond the "berm" built by Moroccan forces in the 1980s, bifurcating the disputed territory in two parts. Second, I rapidly accepted the help of a Sahrawi collaborator on the ground who could help me to get familiar with the situation and to identify and understand successful internet productions. This collaboration seems essential when fieldtrips are short and allows me to keep working with him from afar via internet, emails and Facebook. A third category of choices was about our modes of investigation on the Sahrawi internet productions. It consisted in keeping regular watch of work on the Web and to identify, by myself or with the help of Sahrawi friends, on the ground or at home, broadcasts of interest. Then translation of the poems and songs began at home and was completed on the ground by a contextualization work and by interviews with these productions' authors and cyberactivists. I also tried to investigate the local reception of these successful productions, in different places and political environments.

According to authors like Althabe (1969), Fabian (1983), Dozon (2006), we must not separate fieldwork experience from ethnographic knowledge. The idea is to make the fieldwork relationships the basis of the knowledge process. For 
Dozon, we must stop desensitizing fieldwork in the name of a pseudo "objectivity" and privilege the heuristic dimension of the ethnographic relationship.

But the question at stake remains the place of ethnography in "sensitive" terrains. If ethnography as Malinowski codified its principles cannot be implemented, then which ethnography can be implemented, and for which data? Can we avoid the fieldwork stage for another type of ethnography? Is remote ethnography from afar possible thanks to telecommunication facilities (telephone, skype, etc.) and above all is it relevant regarding scientific criteria? For scholars such as Bouju (2015), Hagberg and Körling (2015), we can conduct an anthropological survey from afar, but a previous familiarity with the "terrain" remains irreplaceable. Can we do anthropology without ethnography as Copans (2015) asks, especially at a period when fieldwork seems to define anthropology, much more than theoretical debates did 40 years ago? Are we allowed to forgo fieldwork in sensitive contexts, when the legitimacy of our science is based on this particular qualitative approach and when we realize how difficult it was for ethnology to make its own and distinctive position in the social sciences landscape at the beginning of the 20th century, especially in France (Sibeud 1994, 2004; Grognet 2013)? Or is it only a question of (re)definition of "fieldwork", when the "terrain" appears more constructed than pre-existing (Bouillon et al. 2006: 20), a space ("lieu") of intelligence in a globalized world more than a proper geographic place, another (intellectual) space where ethnographers can build knowledge.

Beyond the question of the possibility of ethnography in dangerous contexts, the issue of the researcher's autonomy is at stake. In social sciences, researchers must preserve their autonomy of thought and action, even if it is limited in a context of tight control over their work. Restrictions on our works heavily impact the way we conduct our research. So we always have to negotiate these conditions of autonomy (Vidal 2009), not only with political institutions but also with our "hosts" and fieldwork interlocutors. This autonomy, even limited, is vital to the quality of our work. It pushes us sometimes to defy or to bypass rules or prohibitions imposed to us: for instance, to enter prohibited grounds as "tourists" in order to escape political limitations of access.

For example, in France, over the last decade or so, research institutions have increasingly imposed restrictions on travel in countries declared "at risk" or located in areas considered dangerous, that the French Ministry of Foreign Affairs will color "orange" or even "red" according to the estimated level of risk. This policy totally closes access to geographical areas where the risks involved exist but are very low relatively to other regions of the world left accessible, where yet the level of crime is known to be high (starting with European countries with recent "jihadist" attacks). This double standard policy, in addition to increasing the difficulties of countries which do not need to see their relations with foreign countries 
retract, ${ }^{9}$ tends to push researchers, who are specialists of these regions and wish to pursue research in which they have often been invested for many years (language learning, collaborations with local researchers, training of students, etc.), to do fieldwork inquiries outside their status of researchers (tourist, journalist, consultant, etc.). This can deprive them of the material and institutional support necessary to carry out their missions in optimal working conditions (travel, accompaniment, security).

Despite all these difficulties and methodological issues, which are hard to manage, especially for students, sensitive fieldwork still evokes interest among scholars and students. More than an heroic quest or a fascination for exceptional situations under media attention, more than a professional strategy to become an expert of a sensitive (and publicized) issue, these sensitive "terrains" are often seen by scholars as an opportunity to combine research and citizen engagement for a fair cause.

\section{The anthropologist's ethics, between objectivity and engagement}

This brings us to a last question, the responsibility of anthropologists in "sensitive" contexts, and the ethic issue: can we conduct ethnographic studies in sensitive or tragic situations (refugees, wars, poverty) and reject in the name of objectivity a certain kind of responsibility regarding the population amongst whom we have been living for a few weeks or months? For Terray, "even if one can not make absolute separation between the researcher and the activist, the two activities are not compatible in time and space, that is to say at the same place and at the same time because they are animated by different logics" (Agier et al. 2015: 27). Moussaoui (2001) reminds us that intellectuals remain the witnesses of their time and, as citizens, have the duty to witness the realities that they observe. Wacquant underlines the tension between the European tradition, and especially the French one, of the intellectual involved in the City and who has the duty to "reinject into the civic and political sphere the fruit of his reflections and his observations", and a North American tradition in which the researcher's ideal is embodied by the professional 10 "possessing technical competence and expert knowledge that is neutral knowledge" and "who must stay away from public debate" (Wacquant 2008). For Scheper-Hughes (1995), in a stimulating debate with Roy D'Andrade on objectivity and militancy, the survey relationship creates a relation of empathy and

${ }^{9}$ For example, to develop cultural and trekking tourism projects, like in Mauritania where this promising economy has been stopped in 2007 and may start again in 2018, just because the French Ministry of Foreign Affairs decided in 2017 to take out the Adrar region of its "red" zones.

${ }^{10}$ Italicized by the authors. 
solidarity with the Other, ${ }^{11}$ what she calls the "primacy of the ethical". According to her, it is the main difference between anthropology as an actor and anthropology as a "spectator". "Anthropologists as witnesses are accountable for what they see and what they fail to see" in critical situations and "anthropological writing can be a site of resistance" (Scheper-Hughes 1995: 419, 420).

For Jonathan Friedman (1995), commenting Nancy Scheper-Hughes, the risk of her position is to propose a politically and morally correct anthropology, and even to become instrumentalized by the population. It is true that frequently, in sensitive situations, we are asked to defend and to carry the population's claims in return for an interview or information, especially when our government is largely responsible for the conflict irresolution (like French government on Western Sahara). But the compromise between engagement and research is not that simple and entails other problems: how to take sides and claim a certain freedom of thought at the same time, and to avoid the risk for - more or less conscious self-censorship? Very often, especially in conflict situations, even the words and categories that we employ to speak about a situation of war, repression, exile, refugees, etc. can be polemical, as I said earlier. Moreover, engagement on a certain side is often a condition for ethnographers to accept in order to work under the protection of one of the two opposite camps: it opens some doors while it closes others. This explains why some anthropologists cannot endorse a "neutral" position and can very hardly work on both sides of a conflict.

Indeed, the meaning of "engagement" is different between scholars. For most of us, high quality research is already a form of engagement because it can bring a rigorous analysis of a very complex (conflict) situation and, doing so, will naturally help in the understanding and the resolution of a conflict, but will also and inevitably appear to be "in favor of" one of the two camps/parties. Beyond that, when we see ${ }^{12}$ refugees living for four decades in very harsh conditions and waiting for the application of international law, can we keep considering that our analyses and publications "are enough" to help in rapidly bringing solutions to their harsh living conditions? Of course, this issue is also about our capacity to control our emotions. But personally, I think that we cannot escape from the population's demands of justice and, as scholars, we can play a very important role at least to meet international and national political actors to inform them and to help them to make (the right) decisions or to work with them on conflict (re)solutions and advocacy.

${ }^{11}$ See for instance an interview of the Spanish anthropologist Juan Carlos Gimeno Martín, who has conducted projects of culture and memory conservation with nationalist poets of the Sahrawi refugee camps in Tindouf, and the SADR ministry of culture (Gimeno Martín, Freire \& Boulay 2017).

12 As for instance Wilson (2016) did in long fieldtrips, for a remarkable ethnography of the Tindouf refugee camps. 
Finally, the crucial question that always remains for us is how to maintain ethnographic data quality and avoid risk of journalistic data showing a lack of deep understanding, the risk of data oriented on "victims" without data crosschecking, and the lack of data contextualization and over-interpretation of actors' speeches, which is a crucial and recurrent bias in ethnography (Olivier de Sardan 1996). Then, it is always our responsibility to look for counter-examples in order to give a place to dissidents or at least un official discourses. And it is also essential to always recognise the position from which we speak, ${ }^{13}$ in order not to let people think that our perspective or analysis represents a general point of view. For instance, Sahrawi Human Rights activists' discourse does not represent all Sahrawi people's point of view. So, it is crucial to situate ourselves and to cross our data with colleagues working on other points of view. Of course, the most "comfortable" position for anthropologists may be that of international law and (Western definitions of) human rights, but this can lead us to focus too narrowly on the application of international principles of law and justice that are often far removed from peoples' realities, daily problems, and expectations.

\section{Conclusion}

We all have different sensitivities to the fieldwork situation and very diverse conceptions of commitment according to our experience, education, personal situation... and career projections. We do not perceive the "sensitive" character of a fieldwork in the same way at age 25 as at age 45 , because we have changed, we have strengthened our methodological skills, we have acquired a greater ability to generalise, and our level of politicization is no longer the same. This is undoubtedly what makes the richness of our exchanges and the debates that we have between us on these questions. I am not embarrassed today to make two-week fieldtrips, which would have seemed aberrant to me 10 or 20 years ago, and it is obvious that the estimation of a fieldwork sensitivity will be amplified on very short trip. But I should probably worry about what will appear to some colleagues as a blatant lack of professionalism?

The fact remains that the discomfort felt on the ground, whether this terrain is deemed "sensitive" or not, does indeed appear to be a powerful driver of renewal of ethnographic methods and a formidable invitation to reflexivity, regardless of our conception of the usefulness of our interventions in the field. However, we must ask whether the state of the contemporary world, where the happiness of

${ }_{13}$ Proposition made by Pénélope Larzillière (IRD) within the doctoral seminar "Enquêter en terrain sensible", Doctoral School (ED 180) of the Faculty of Human and Social Sciences of the Sorbonne (Paris Descartes University) held on January $19^{\text {th }}$ and $26^{\text {th }}, 2017$. 
some seems possible only at the expense of the misfortune of others, still allows researchers to hide behind an increasingly illusory claim to political neutrality.

\section{Bibliography}

Agier M. (ed.)

1997 Anthropologues en danger, Paris.

Agier M., Dozon J.-P., Ticktin M., Bertho A., Balibar E., Terray E.

2015 Une anthropologie citoyenne? Militantisme, engagement et critique sociale, [in:] Repenser l'anthropologie aujourd'hui avec Emmanuel Terray ( Les actes »), 22 septembre 2015, Consulté le 24 novembre 2017, http://actesbranly.revues.org/638, (access: 16.08.2017).

Albera D. (ed.)

2001 Terrains minés en ethnologie, "Ethnologie française", No. 1, p. 5-13.

Althabe G.

1969 Oppression et libération dans l'imaginaire, Paris.

Ayimpam S.

2015 Enquêter en terrains difficiles, "Civilisations”, No. 64, p. 57-66.

Balandier G.

2001 La situation coloniale : approche théorique, "Cahiers internationaux de sociologie", No. 110, p. 9-21.

Bensa A.

2006 La fin de l'exotisme. Essais d'anthropologie critique, "Anacharsis", No. 4, http:// temporalites.revues.org/392 (access: 16.08.2017).

Bensa A., Fassin D. (eds.)

2008 Les politiques de l'enquête. Epreuves ethnographiques, Paris.

Bouillon F., Fresia M., Tallio V. (eds.)

2006 Terrains sensibles, Expériences actuelles de l'anthropologie, coll. Dossiers africains, Paris.

Bouju J.

2015 Une ethnographie à distance?, "Civilisations", No. 64, http://civilisations.revues. org/3933 (access: 16.08.2017).

Boulay S.

2014 Le terrain comme chantier de l'anthropologue : exemples denquêtes ethnographiques menées dans l'ouest du Sahara, [in:] Travailler ensemble? Des disciplines aux sciences sociales, ed. C. Chevandier, Mont-Saint-Aignan, p. 155-167.

2015 Techniques, poésie et politique au Sahara Occidental, "L'Homme”, No. 215-216, p. 251-278.

2016 'Returnees' and Political Poetry in Western Sahara: Defamation, Deterrence and Mobilization on the Web and Mobile Phones, "The Journal of North African Studies", No. 21(4), p. 667-686.

2017 Corps, tentes et campements en mouvements : texture du politique au Sahara Occidental, [in :] Culture et politique dans l'Ouest saharien: Arts, activisme et État dans un espace de conflits, ed. S. Boulay, F. Freire, Igé, p. 391-422. 
Boulay S., Dahmi M.

2017 Humour, dérision et diffamation au Sahara Occidental: Quand les artistes sahraouis s'emparent des nouveaux medias pour critiquer le pouvoir, https://hal.archives-ouvertes.fr/hal-01456970 (access: 16.08.2017).

Caratini S.

2003 La République des sables. Anthropologie d'une Révolution, Paris.

2012 Les non-dits de l'anthropologie, Vincennes.

Clifford J.

2003 De l'autorité en ethnographie. Le récit anthropologique comme texte littéraire, [in:] L'enquête de terrain, ed. D. Céfai, Paris, p. 263-294.

Copans J.

2015 Lappel de la théorie : le terrain le plus difficile, "Civilisations”, No. 64, http://civilisations.revues.org/3943 (access: 16.08.2017).

Deubel T.F.

2012 Poetics of Diaspora: Sahrawi Poets and Postcolonial Transformations of a TransSaharan Genre in Northwest Africa, "The Journal of North African Studies", 17, 2, p. 295-314.

2017 Nostalgia, Memory and Nationalism. Homeland Poetry and Identity Politics in Sahrawi Communities, [in:] Culture et politique dans l'Ouest saharien: Arts, activisme et État dans un espace de conflits, ed. S. Boulay, F. Freire, Igé, p. 127-154.

Dozon J.-P.

2006 Préface, [in:] Terrains sensibles, Expériences actuelles de l'anthropologie, ed. F. Bouillon, M. Fresia, V. Tallio, coll. Dossiers africains, Paris, p. 7-11.

Fabian J.

1983 Time and the Other: How Anthropology Makes its Object, New York.

Fassin D.

2006 L'innocence perdue de l'anthropologie : remarques sur les terrains sensibles, [in:] Terrains sensibles, Expériences actuelles de l'anthropologie, ed. F. Bouillon, M. Fresia, V. Tallio, coll. Dossiers africains, Paris, p. 97-103.

Friedman J.

1995 Comments on D’Andrade/Scheper-Hughes Ojectivity and Militancy, "Current Anthropology", No. 36(3), p. 421-423.

Gimeno Martín J.C., Freire F., Boulay S.

2017 Une expérience d'anthropologie engagée auprès des poètes de la RASD. Entretien avec Juan Carlos Gimeno Martín, [in:] Culture et politique dans l'Ouest saharien, : Arts, activisme et État dans un espace de conflits, ed. S. Boulay, F. Freire, Igé, p. 185-207.

Grognet F.

2013 Quand l'ethnographie défie l'anthropologie. Le tournant manqué du Musée d'Ethnographie du Trocadéro, [in:] 1913 La recomposition de la science de l'Homme, ed. Ch. Laurière, Les carnets de Bérose, 7, p. 64-88, https://halshs.archives-ouvertes.fr/ halshs-01147862 (access : 16.08.2017).

Hagberg S., Körling G.

2015 Terrains inaccessibles, "Civilisations”, No. 64, http://civilisations.revues.org/3929 (access: 16.08.2017).

Larzillière $\mathrm{P}$.

2016 Activism in Jordan: Methodological Appendix, Londres.

Leiris M.

1950 L'ethnographe devant le colonialisme, "Les temps modernes", No. 58, p. 357-374. 
Malinowski B.

1985 [1967, éd. originale en anglais], Journal d'ethnographe, Paris.

1989 [1922], Les Argonautes du Pacifique Occidental, Paris.

Marcus G.A.

1995 Ethnography in/of the World System: The Emergence of Multi-Sited Ethnography, "Annual Review of Anthropology", No. 24, p. 95-117.

Moussaoui A.

2001 Du danger et du terrain en Algérie, "Ethnologie française”, No. 1, p. 51-59.

Olivier de Sardan J.-P.

1995 La politique du terrain - Sur la production des données en anthropologie, "Enquête", No. 1, http://enquete.revues.org/263 (access: 16.08.2017).

1996 La violence faite aux données. De quelques figures de la surinterprétation en anthropologie, "Enquête", No. 3, http://enquete.revues.org/363 (access: 16.08.2017).

Ouattara F.

2004 Une étrange familiarité: les exigences de l'anthropologie 'chez soi', "Cahiers d'Etudes Africaines", XLIV, 3, 175, p. 635-657.

Pétonnet C.

1982 Lobservation flottante. L'exemple d'un cimetière parisien, "L'Homme", XXII (4), p. 37-47.

Prud'homme P.

2015 L'imam, l'expert et le diplomate, "Civilisations", No. 64, http://civilisations.revues. org/3918 (access: 16.08.2017).

Rabinow P., Marcus G., Faubion J., Rees T.

2008 Designs for an Anthropology of the Contemporary, Durham, N.C.

Robben A.C.G.M., Nordstrom C. (eds.)

1996 Fieldwork under Fire. Contemporary Studies of Violence and Culture, Berkeley.

Robles Picón J.I., Gimeno Martín J.C., Awah B.M., Laman M.A.

2015 La poésie sahraouie dans la naissance de la conscience nationale, [in:] Sahara occidental: mémoires, culture, histoires, "Cahiers d'EMAM", No. 24-25, http://emam.revues.org/781 (access: 30.06.2015).

Scheper-Hughes N.

1995, The Primacy of the Ethical, "Current anthropology", No. 36(3), p. 409-440.

Schinz O.

2002 Pourquoi les ethnologues sétablissent en enfer? Maîtrise de soi, maîtrise de son terrain, http://www.ethnographiques.org/2002/Schinz.html (access: 30.06.2015).

Sibeud E.

1994 La naissance de l'ethnographie africaniste en France avant 1914, "Cahiers d'études africaines", 34(136), p. 639-658.

2004 Marcel Mauss: 'Projet de présentation d'un bureau d'ethnologie' (1913), "Revue d'Histoire des Sciences Humaines", No. 10, p. 105-115.

Sluka J.A. (ed.)

2000 Death Squad. The Anthropology of State Terror, Philadelphia.

Todorov T. (ed.)

2007 Le siècle de Germaine Tillion, Paris.

van Wyk I.

2013 Beyond Ethical Imperatives in South African Anthropology: Morally Repugnant and Unlikeable Subjects, "Anthropology Southern Africa" 36 (1-2), p. 68-79. 
Vidal L.

2009 L'anthropologie de l'aide humanitaire et du développement. Entre exigences méthodologiques, ambition épistémologique et souci éthique, [in:] Anthropologie de l'aide humanitaire et du développement. Des pratiques aux savoirs, des savoirs aux pratiques, ed. L. Atlani-Duault, L. Vidal, Paris, p. 229-252.

Wacquant L.

2008 Le corps, le ghetto et l'État pénal, "Labyrinthe”, No. 31(3), http://labyrinthe.revues.org/3920 (access: 30.06.2015).

Wilson A.

2016 Sovereignty in Exile, A Saharan Liberation Movement Governs, Philadelphia. Zunes S., Mundy J.

2010 Western Sahara: War, Nationalism, and Conflict Irresolution, Syracuse. 